\title{
The Trans-Pacific Partnership
}

\section{Challenges for the Canadian health care system and developing world}

\author{
Adam Kovacs-Litman, Cory Lefebvre, Lauren Crosby \\ Faculty Reviewer: Fawaz Siddiqi, MD, MBA, FRCSC, FACS (Department of Clinical Neurological Sciences)
}

\section{A NEW TYPE OF TRADE AGREEMENT}

Free trade agreements are often lauded by economists. Excessive tariffs, subsidies and regulations distort international and domestic markets. It is the lifting of restrictions on imports and exports that allows countries to trade more easily and realize economic efficiencies that benefit all parties involved. The Trans-Pacific Partnership (TPP), signed on 4 February 2016, is a free trade agreement of tremendous scope, yet experts are wary of the agreement's implications on the sovereignty of its signatories. ${ }^{1}$ Unlike other free trade agreements, the TPP does not seek to dismantle regulations, but rather to harmonize domestic policy between nations. ${ }^{2}$ The TPP seeks to achieve "free trade" not through the elimination of regulations but through international conformity in regional legislation. ${ }^{2}$ The lowering of trade barriers seems almost incidental.

When the ТРP enters into force, it will eliminate tariff and nontariff barriers to trade while introducing stringent regulations on environmental protection, minimum working conditions, intellectual property and quality control of food and drug products. Prospective signatories are Australia, Brunei, Canada, Chile, Japan, Malaysia, Mexico, New Zealand, Peru, Singapore, the United States (US) and Vietnam, but the agreement is structured such that other countries may sign on at a later date. ${ }^{3}$ The TPP will be the largest trade agreement ever attempted, and the seminal trade deal of the 21 st century. The TPP countries have a combined gross domestic product (GDP) of over US\$26 trillion and US $\$ 5$ trillion in goods and services. This is over $40 \%$ of the world's GDP and includes almost 800 million people. ${ }^{4}$ The significance of this agreement should not be understated.

Critics of the TPP are particularly suspicious of its implications for intellectual property and privacy. The intellectual property provisions in particular could have far-reaching ramifications for health care in Canada, other developed nations and the developing world. In Canada, the TPP may limit the ability of federal and provincial governments to legislate public health efforts when those efforts clash with the interests of industry. ${ }^{5}$ Additionally, the TPP may drive up the cost of pharmaceutical products by enshrining special legal protections for pharmaceutical companies and decreasing the Canadian government's ability to effectively regulate them. ${ }^{6}$ The plight of the developing world is even worse. Increases in patent term length, drug cost and decreased availability of generic drugs will likely deny millions of people access to essential lifesaving medications.

\section{HEALTH CARE IN CANADA}

The Canadian health care system may not be perfect, but it is a far cry from the inefficiencies of the US system. Even after account- ing for differences in the strength of the Canadian and US dollars, drug prices in the US are approximately $32 \%$ greater than in Canada. ${ }^{8}$ This gap could be widened further with the introduction of a national Canadian pharmacare plan. ${ }^{9}$ The TPP may expose Canada to the same inefficiencies experienced by the US and limit our ability to change health policy going forward, such as creating any kind of unified national pharmacare strategy. ${ }^{6}$

The TPP limits the ability of Canadian and provincial governments to legislate public health efforts. In chapter 16, "Competition Policy," the TPP directly limits the regulation of consumer products. Any law that limits the competitiveness of a corporation would be discouraged or forbidden by the TPP..$^{10}$ This could have broad implications for: product labelling, advertising, nutritional requirements, quality control, and taxation (especially for excise taxes). ${ }^{11}$ Though the TPP would allow for certain exemptions from its competition clause, it is unclear how and where they would apply. ${ }^{10}$ In chapter 26, "Transparency and Anti-Corruption," the TPP enshrines the right of industry to contribute to national nutrition policy thereby increasing the lobbying power of large corporations. ${ }^{11,12}$ These sections undermine Canada's mission to combat chronic noncommunicable diseases like diabetes and heart disease and severely limit the options available to regulators and health policy experts.

The investor-state dispute settlement mechanism outlined in chapter 28, "Dispute Settlement," creates an internationally recognized panel whereby private institutions can pursue legal action against countries. ${ }^{13}$ This chapter vastly increases the legal powers of corporations and gives pharmaceutical companies a powerful piece of leverage, which may be used to extract economic rents in court or during the bargaining phase of contract negotiation. The Canadian government is already being sued by US drug company Alexion Pharmaceuticals, who alleges that the Canadian government unfairly lowered the cost of their drug Soliris. ${ }^{14}$ Even if the Canadian government wins this lawsuit, the Canadian public will have lost. Money that could have been spent on public health projects by Health Canada or research and development by Alexion Pharmaceuticals will have been wasted in the courts. The new anticompetition clauses of chapter 16 coupled with the easily accessed dispute settlement mechanism of chapter 28 will likely see such lawsuits become more commonplace. Moreover, even if this policy does not encourage increased legal action in Canada, the mere threat of legal action may prompt a rise in drug prices.

\section{HEALTH CARE IN THE DEVELOPING WORLD}

The humanitarian organization Doctors Without Borders/Médecins Sans Frontières (MSF) has publicly condemned the TPP for what they view as an agreement that places dangerous restrictions 
on medications in the developing world. ${ }^{7}$ Lack of access to essential medicines is estimated to result in over 40 million deaths in the developing world..$^{15}$ Policies that raise the cost of drugs through increasing the enforceability and length of patents will only see this number rise. ${ }^{16}$

Chapter 18 of the TPP, "Intellectual Property," has been the document's most contentious area. It introduces a number of policies that define the minimum length of patent protection and outlines mandatory criteria for patent extension, including a 3-year extension for a new indication and a 5 -year extension for a change in chemical structure. ${ }^{17}$ In Canada, the length of a pharmaceutical patent is already 20 years, but the duration is considerably lower in a number of developing countries if protections exist at all. Many developing nations have intentionally loose patent regulations so that they can produce or purchase generic alternatives to brand name drugs that are beyond the financial reach of many of their citizens. ${ }^{18}$

MSF purchases over $80 \%$ of their antiretroviral drugs (drugs used in the treatment of human immunodeficiency virus/acquired immunodeficiency syndrome) from India, a country famous for skirting US patent law. India has a history of ignoring the validity of US patents and producing their own generics long before patent expiry. ${ }^{7}$ Like MSF, many developing nations rely on India as a cheap source of life-saving medications. ${ }^{19}$ Though India is not a signatory of the TPP, signatories that continue to purchase protected drugs from India will face steep fines for violating the "Competition Policy" and "Intellectual Property" chapters of the TPP..$^{10,17}$

Biologics and biosimilars (their generic counterparts) are large complex molecules that are manufactured in the living system of a microorganism. These drugs are becoming increasingly important in the creation of vaccines, blood components, allergenics, gene therapy and in the treatment of a host of immune-mediated disorders including some cancers, rheumatoid arthritis, inflammatory bowel disease and many others. Due to the incredible complexity of these drugs, manufacturers of biosimilars rely on data from the clinical trials of the original biologic and still require 7 to 8 years and between US\$100-US\$250 million USD to bring products to market. $^{20}$ The barriers to entry for the biosimilars market are already tremendous, yet the TPP mandates 10 years of data exclusivity for biologics. ${ }^{17}$ Brunei, Peru, Vietnam, Malaysia and Mexico currently have 0 years of data exclusivity while Japan has $8 .^{7}$ The TPP will likely markedly increase the cost of such drugs in the developing world, limiting the treatment options available to all but the richest segments of the population.

\section{A WOLF IN SHEEP'S CLOTHING}

The TPP is the most ambitious free trade agreement ever attempted. It opens the borders between 12 countries across North America and the Asia-Pacific region while instituting mandatory statutes for worker safety and environmental protection. This trade agreement could be a revolution in global commerce, but the TPP is so much more than just a free trade agreement. Its 30 chapters introduce a host of regulations that restrict certain domestic policies while mandating the legislation of others. The regulations it introduces and the precedent it creates will steer international markets as well as individual countries and guide their future de- velopment for years to come. Unfortunately, the agreement seems to sacrifice the global health care system on the altar of economic progress. Increased pharmaceutical costs, decreased autonomy in legislating public health solutions and decreased access to generics and biosimilars, particularly in the developing world, is a price that seems too great to bear.

The TPP is perhaps the greatest trade agreement ever created, but it is an agreement ruled by its subtexts.

\section{REFERENCES}

1. Baldwin RE. 21st Century Regionalism: Filling the gap between 21st century trade and 20th century trade rules. Available at SSRN 1869845. 2011 Apr.

2. Fergusson IF, Cooper WH, Jurenas R, Williams BR. The Trans-Pacific Partnership: negotiations and issues for congress. Digital Commons. 2013 Aug.

3. Williams BR. Trans-Pacific Partnership (TPP) countries: comparative trade and economic analysis. Digital Commons. 2013 Jan.

4. Schott JJ, Kotschwar B, Muir J. Understanding the Trans-Pacific Partnership. Peterson Institute. 2013 Jan.

5. Kapczynski A. The Trans-Pacific Partnership-is it bad for your health? N Engl J Med. 2015 Jul;373(3):201-203.

6. Thow AM, Gleeson DH, Friel S. What doctors should know about the Trans-Pacific Partnership agreement. Med J Aust. 2015 Mar;202(4):165-166.

7. MSF. Trading Away Health. [Internet]. New York (USA); MSF; 2012 [cited 2015 Nov 19]. Available from: http://www.msfaccess.org/ sites/default/files/MSF_assets/Access/Docs/Access_Briefing_TPP_ ENG_2012_update.pdf

8. Danzon PM, Kim JD. International price comparisons for pharmaceuticals. Pharmacoeconomics. 1998 Nov;14(1):115-128.

9. Morgan SG, Daw JR, Law MR. Rethinking Pharmacare in Canada. 2013 Jun;384.

10. Office of the United States Trade Representative. TPP Chapter 16; Competition. [Internet]. United States; 2015 [cited 2015 Nov 19]. Available from: https://ustr.gov/sites/default/files/TPP-Final-Text-Competition.pdf

11. Thow AM, Snowdon W, Labonté R, Gleeson D, Stuckler D, Hattersley $\mathrm{L}$, et al. Will the next generation of preferential trade and investment agreements undermine prevention of noncommunicable diseases? A prospective policy analysis of the Trans Pacific Partnership Agreement. Health Policy. 2015 Jan;119(1):88-96.

12. Office of the United States Trade Representative. TPP Chapter 26; Transparency and anti-corruption. [Internet]. United States; 2015 [cited 2015 Nov 19]. Available from: https://ustr.gov/sites/default/files/ TPP-Final-Text-Transparency-and-Anti-corruption.pdf

13. Office of the United States Trade Representative. TPP Chapter 28; Dispute Settlement. [Internet]. United States; 2015 [cited 2015 Nov 19]. Available from: https://ustr.gov/sites/default/files/TPP-Final-Text-Dispute-Settlement.pdf

14. CBC News. U.S. drug company sues Canada for trying to lower cost of $\$ 700 \mathrm{~K}$-a-year drug. Canada; 2015 [cited 2015 Nov 19]. Available from: http://www.cbc.ca/news/health/u-s-drug-company-sues-canada-fortrying-to-lower-cost-of-700k-a-year-drug-1.3242172

15. World Health Organization. WHO model list of essential medicines: 19th list (updated) April 2015. 2015 Apr.

16. Attaran A. How do patents and economic policies affect access to essential medicines in developing countries? Health Affairs. 2004 May;23(3):155-66. 
17. Office of the United States Trade Representative. TPP Chapter 18; Intellectual property. [Internet]. United States; 2015 [cited 2015 Nov 19]. Available from: https://ustr.gov/sites/default/files/TPP-Final-Text-Competition.pdf

18. Luo J, Kesselheim AS. The Trans-Pacific Partnership agreement and implications for access to essential medicines. JAMA. 2015 Oct.

19. Lynch S, Ford N, van Cutsem G, Bygrave H, Janssens B, Decroo T, et al. Getting HIV treatment to the most people. Science. 2012 Jul;337(6092):298-300.

20. Blackstone EA, Joseph PF. The economics of biosimilars. AHDB. 2013 Sep;6(8):469. 